\title{
Maturity Pattern of Assets and Liabilities: A Case Study of Canara Bank
}

\author{
S.S. Hugar \\ Karnatak University, Dharwad, India \\ Ronil K Manohar \\ Karnatak University, Dharwad, India
}

\begin{abstract}
This paper discusses the issues in relating to the maturity pattern of asset and liabilities of the bank i.e. Canara bank under study. It examines the maturity patterns of both assets and liabilities under different time buckets and analyses the implication of different mismatches. It also throws on the impact of an overall gap on bank's profitability and liquidity and elaborates on various categories of risk that require to be managed. The data had been collected from the secondary sources such as annual reports of Canara Bank, reports and websites etc. It has been found in the study that proper liability mix technique is a successful tool for minimizing the risk.

Keywords---liability - mix, risk management, time-buckets.
\end{abstract}

\section{Introduction}

Liability- a mix of a bank consists of both interest-bearing liabilities (like borrowings, deposits, etc.) and non-interest bearing liabilities (like share capital, reserves, and surplus, etc.). Asset Mix of Canara Bank consists of cash and balance with RBI, investments, advances, fixed assets, and other assets. A bank is said to be highly levered provided the proportion of interest-bearing liabilities to non-interest bearing liabilities is relatively more and vice-versa. A levered bank can maximize the shareholders' wealth provided the average interest expense i.e. the cost of debt (Kd) is more than the cost of equity (Ke). Hence, the liability structure of a bank determines its cost of debt's degree of financial leverage and the capacity of the bank to magnify the effect of a change in interest income on shareholders' equity. In the light of this background, the maturity pattern of asset and liabilities of the bank under study is analyzed and liability-mix of the Canara Bank is analyzed with the help of financial ratios with ANOVA techniques.

Objectives of the Study:

a) To analyze the maturity pattern of assets of the bank

b) To analyze the maturity pattern of liabilities of the bank.

c) To analyze the maturity gap between total inflows and total outflows of Canara Bank.

d) To offer useful suggestions.

Hypotheses of the Study:

a) Testing of the significance of the variations in the maturity pattern of assets.

1) $\mathrm{H}_{0}$ : There is no relationship between maturity pattern and loans and advances, investment and securities, interest-earning assets, borrowings and interest borrowings and interest-bearing liabilities of Canara Bank.

2) $\mathrm{H}_{\mathrm{a}}$ : There is a relationship between maturity pattern and loans and advances, investment and securities, interest-earning assets, borrowings and interest borrowings and interest-bearing liabilities of Canara Bank. 
b) Testing of the significance of the variations in the maturity pattern of liability.

1) $\mathrm{H}_{0}$ : There are no significant differences between maturity pattern inflows and outflows of Canara Bank over the different maturity periods.

2) $\mathrm{H}_{\mathrm{a}}$ : There are significant differences between maturity pattern inflows and outflows of Canara Bank over the different maturity periods.

c) Testing of the Significance in the variations among maturity gaps between total inflows and total outflows.

1) $\mathrm{H}_{0}$ : There is no significant variation among maturity gaps between total inflows and total outflows.

2) $\mathrm{H}_{1}$ : There is significant variation among maturity gaps between total inflows and total outflows.

\section{Research Method}

a) Database: The present study is mainly based on secondary data collected from annual reports of Canara Bank, books, journals and magazines besides the following websites

b) A tool used for analysis and interpretation of data: The collected data have been properly classified, tabulated and processed by applying different financial ratios. Further, to examine the significance of the variations in the maturity pattern of assets and liabilities and the maturity gap, the ANOVA technique has been used.

\section{Results and Analysis}

\section{Analysis of Maturity Pattern of Assets and Liabilities:}

As per the guidelines issued by the RBI, every commercial bank has to classify its assets and liabilities in different time buckets (on the basis of remaining maturity). Accordingly, the bank under study has classified its assets and liabilities into an eight-time buckets viz.
a) Time bucket of 1-14 days
b) Time bucket of 15-28 days
c) Time bucket of 29 days-3 months
d) Time bucket of over 3 months, up to 6 months
e) Time bucket of over 6 months, up to 1 year
f) Time bucket of over 1 year, up to 3 years
g) Time bucket of over 3 years, up to 5 years
h) Time bucket of over 5 years

Analysis of the assets across the different time buckets reflects the extent of funds deployed in each time bucket and the date of maturity. The larger the amount of money deployed in the time bucket of longer duration, the higher the profitability of the bank, other things being equal and vice versa.

Table 3

Maturity Pattern of Loans and Advances

\begin{tabular}{|c|c|c|c|c|c|c|c|c|c|}
\hline \multirow[b]{2}{*}{ Year } & & & & & & \\
\hline & & $\begin{array}{l}15 \text { Days to } \\
28 \text { Days }\end{array}$ & $\begin{array}{l}29 \text { Days } \\
\text { to } 3 \text { Months }\end{array}$ & $\begin{array}{l}3 \text { Months } \\
\text { to } 6 \text { Months }\end{array}$ & $\begin{array}{l}6 \text { Months } \\
\text { to } 1 \text { Year }\end{array}$ & $\begin{array}{l}1 \text { Year } \\
\text { to } 3 \text { Years }\end{array}$ & $\begin{array}{l}3 \text { Years } \\
\text { to } 5 \text { Years }\end{array}$ & $\begin{array}{l}\text { Over } 5 \\
\text { Years }\end{array}$ & Total \\
\hline $2010-11$ & 21445.78 & 6660.35 & 25999.52 & 19908.20 & 32275.38 & 48708.99 & 21956.46 & 35512.50 & 212467.17 \\
\hline 2011-12 & 23331.99 & 7072.99 & 26996.74 & 21003.96 & 32222.77 & 57403.00 & 24790.81 & 39712.56 & 232489.82 \\
\hline 2012-13 & 19301.35 & 9021.95 & 22667.97 & 20930.30 & 39728.83 & 65415.73 & 23289.20 & 42358.29 & 242176.62 \\
\hline 2013-14 & 34243.00 & 16231.00 & 20701.00 & 21463.00 & 40135.00 & 76365.00 & 27975.00 & 63954.00 & 301067.00 \\
\hline 2014-15 & 37270.79 & 14575.33 & 28135.10 & 20837.77 & 47128.30 & 82604.60 & 35902.27 & 63581.35 & 330035.51 \\
\hline \multicolumn{10}{|c|}{ Two-way ANOVA } \\
\hline \multicolumn{2}{|c|}{ Source of Variation } & \multicolumn{2}{|l|}{ SS } & Df & MS & $\mathrm{F}$ & & P-Value & F Crit \\
\hline \multirow{2}{*}{\multicolumn{2}{|c|}{$\begin{array}{l}\text { Row } \\
\text { Columns }\end{array}$}} & \multicolumn{2}{|c|}{1229146346.22} & 4 & 307286586.6 & 9.19575 & & 0.00007 & 2.7141 \\
\hline & & \multirow{2}{*}{\multicolumn{2}{|c|}{$\begin{array}{l}10820668822.85 \\
935652264.79\end{array}$}} & 7 & 1545809831.8 & 46.2593 & & 9.9699 & 2.3593 \\
\hline \multicolumn{2}{|l|}{ Error } & & & 28 & 33416152.31 & & & & \\
\hline \multicolumn{2}{|l|}{ Total } & \multicolumn{2}{|c|}{12985467433.865} & 39 & & & & & \\
\hline
\end{tabular}

Source: Annual Reports of Canara Bank 
Table 3 indicates that most of the loans and advances fall in the time bucket of 1-3 years and over 5 years. This indicates that earning-assets-mix has a favourable impact on bank's profitability, other things being equal.

Table 4

Maturity Pattern of Investments and Securities of Canara Bank

\begin{tabular}{|c|c|c|c|c|c|c|c|c|c|}
\hline \multirow[b]{2}{*}{ Year } & \multirow[b]{2}{*}{$\begin{array}{l}\text { 1 Day to } \\
14 \text { Days }\end{array}$} & \multirow[b]{2}{*}{$\begin{array}{l}15 \text { Days } \\
\text { to } 28 \\
\text { Days }\end{array}$} & \multirow[b]{2}{*}{$\begin{array}{l}29 \text { Days to } \\
3 \text { Months }\end{array}$} & \multirow[b]{2}{*}{$\begin{array}{l}3 \text { Months } \\
\text { to } 6 \\
\text { Months }\end{array}$} & \multirow[b]{2}{*}{$\begin{array}{l}6 \text { Months to } \\
1 \text { Year }\end{array}$} & \multirow[b]{2}{*}{$\begin{array}{l}1 \text { Year to } 3 \\
\text { Years }\end{array}$} & \multirow[b]{2}{*}{$\begin{array}{l}3 \text { Years to } 5 \\
\text { Years }\end{array}$} & \multicolumn{2}{|c|}{ (Rs. in Crore) } \\
\hline & & & & & & & & Over 5 Years & Total \\
\hline $2010-11$ & 1085.58 & 667.29 & 10374.70 & 1022.78 & 960.50 & 1624.77 & 8165.77 & 59798.53 & 83699.92 \\
\hline 2011-12 & 4319.20 & 1967.46 & 6485.29 & 983.46 & 1550.50 & 3715.24 & 12838.05 & 70198.22 & 102057.42 \\
\hline $2012-13$ & 1709.23 & 2072.29 & 8987.10 & 1557.68 & 1613.55 & 7672.61 & 18699.15 & 78821.22 & 121132.83 \\
\hline 2013-14 & 842.62 & 630.41 & 2406.82 & 1340.02 & 2227.65 & 12332.09 & 30092.29 & 76998.41 & 126870.31 \\
\hline $2014-15$ & 2716.25 & 347.54 & 6867.80 & 3394.47 & 5081.73 & 16868.52 & 32567.18 & 77502.69 & 145346.18 \\
\hline \multicolumn{10}{|c|}{ Two-way ANOVA } \\
\hline \multirow{2}{*}{\multicolumn{2}{|c|}{$\begin{array}{l}\text { Source of Variation } \\
\text { Rows }\end{array}$}} & \multicolumn{2}{|l|}{ SS } & $\mathrm{Df}$ & \multicolumn{2}{|l|}{ MS } & $\mathbf{F}$ & P-Value & F Crit \\
\hline & & \multicolumn{2}{|c|}{280404869.71} & 4 & \multicolumn{2}{|c|}{70101217.427} & 3.064263 & 0.032630 & 2.71407 \\
\hline \multicolumn{2}{|l|}{$\begin{array}{l}\text { Rows } \\
\text { Columns }\end{array}$} & \multirow{2}{*}{\multicolumn{2}{|c|}{ 640556479.07 }} & 7 & \multirow{2}{*}{\multicolumn{2}{|c|}{$\begin{array}{l}2969130555.265 \\
22877017.1096\end{array}$}} & 129.7866 & 129.7866 & 2.35925 \\
\hline \multicolumn{2}{|l|}{ Error } & & & 28 & & & & & \\
\hline otal & & 21704875 & 235.04 & 39 & & & & & \\
\hline
\end{tabular}

Source: Annual Reports of Canara Bank

The number of funds deployed by the bank in investments and securities the particular time bucket in which such assets fall would affect bank's profitability and liquidity. If more and more funds are deployed in shorter time buckets, bank's liquidity will be improved. If the relative share of these falling in time buckets of longer duration is more, both liquidity and profitability would be adversely affected. Table 4 indicates that major portion of the funds deployed in investment is applicable to the time bucket of over 5 years followed by 3 to 5 years. It implies that the impact of investment and securities is not as severe as that of loans and advances.

Table 5

Analysis of Maturity Pattern of Interest Earning Assets

\begin{tabular}{|c|c|c|c|c|c|c|c|c|c|}
\hline \multirow[b]{2}{*}{ Year } & \multirow[b]{2}{*}{$\begin{array}{l}1 \text { Day to } 14 \\
\text { Days }\end{array}$} & \multirow[b]{2}{*}{$\begin{array}{l}15 \text { Days to } \\
28 \text { Days }\end{array}$} & \multirow[b]{2}{*}{$\begin{array}{l}29 \text { Days to } \\
3 \text { Months }\end{array}$} & \multirow[b]{2}{*}{$\begin{array}{l}3 \text { Months } \\
\text { to } 6 \\
\text { Months }\end{array}$} & \multirow[b]{2}{*}{$\begin{array}{l}6 \text { Months } \\
\text { to } 1 \text { Year }\end{array}$} & \multirow[b]{2}{*}{$\begin{array}{l}1 \text { Year to } 3 \\
\text { Years }\end{array}$} & \multirow[b]{2}{*}{$\begin{array}{l}3 \text { Years to } \\
5 \text { Years }\end{array}$} & \multicolumn{2}{|c|}{ (Rs. in Crore) } \\
\hline & & & & & & & & Over 5 Years & Total \\
\hline $2010-11$ & 22531.36 & 7327.64 & 36374.22 & 20930.98 & 33235.88 & 50333.76 & 30122.23 & 95311.03 & 296167.09 \\
\hline 2011-12 & 27651.19 & 8995.45 & 33482.03 & 21987.42 & 33773.27 & 61118.24 & 37628.86 & 109910.78 & 334547.24 \\
\hline 2012-13 & 21010.58 & 11094.24 & 31655.07 & 22487.98 & 41342.38 & 73088.34 & 41988.35 & 121179.51 & 363309.45 \\
\hline 2013-14 & 35085.62 & 16861.41 & 23107.82 & 22803.02 & 42362.65 & 88697.09 & 58067.29 & 140952.41 & 427937.31 \\
\hline 2014-15 & 39987.04 & 14922.87 & 35002.90 & 24232.24 & 52210.03 & 99473.12 & 68469.45 & 141084.04 & 475381.69 \\
\hline \multicolumn{10}{|c|}{ Two-way ANOVA } \\
\hline $\begin{array}{l}\text { Source of } \\
\text { Variation }\end{array}$ & & Df & \multicolumn{2}{|c|}{ MS } & & $\mathrm{F}$ & P-Value & F Crit \\
\hline Rows & \multicolumn{2}{|c|}{2593699888.85} & 4 & \multicolumn{3}{|c|}{648424972.21} & 8.095347 & 0.000180881 & 2.7140758 \\
\hline Columns & \multicolumn{2}{|c|}{43778342026.53} & 7 & \multicolumn{3}{|c|}{6254048860.93} & 78.07950 & 1.1212083 & 2.35925985 \\
\hline Error & \multirow{2}{*}{\multicolumn{2}{|c|}{2242757206.0376}} & 28 & \multicolumn{3}{|c|}{80098471.64} & & & \\
\hline Total & & 799121.4226 & 39 & & & & & & \\
\hline
\end{tabular}

Source: Annual Reports of Canara Bank

The analysis of maturity pattern of interest-earning assets across the different time buckets reflects the extent of funds deployed in each time bucket and the date of maturity. The larger the amount of money deployed in the time bucket of longer duration the higher the profitability of the bank and vice versa. Table 5 reveals those major portions of the funds are deployed in the assets maturing during the period over 5 years. Further, the data indicate that there has been a substantial increase in the size of funds deployed in assets classified under different time buckets. 
Table 6

Maturity Pattern of Borrowing

(Rs. in Crore)

\begin{tabular}{|c|c|c|c|c|c|c|c|c|c|}
\hline Year & $\begin{array}{l}\text { 1 Day to } \\
14 \text { Days }\end{array}$ & $\begin{array}{l}15 \text { Days } \\
\text { to } 28 \\
\text { Days }\end{array}$ & $\begin{array}{l}29 \text { Days } \\
\text { to } 3 \\
\text { Months }\end{array}$ & $\begin{array}{l}3 \text { Months } \\
\text { to } 6 \\
\text { Months }\end{array}$ & $\begin{array}{l}6 \text { Months } \\
\text { to } 1 \text { Year }\end{array}$ & $\begin{array}{l}1 \text { Year to } 3 \\
\text { Years }\end{array}$ & $\begin{array}{l}3 \text { Years to } 5 \\
\text { Years }\end{array}$ & Over 5 Years & Total \\
\hline $2010-11$ & 00.10 & 1567.58 & 0.35 & 835.09 & 81.79 & 4625.86 & 2795.97 & 4355.02 & 14261.65 \\
\hline 2011-12 & 00.00 & 518.06 & 1613.22 & 1286.06 & 25.68 & 2511.14 & 4956.62 & 4614.60 & 15525.39 \\
\hline $2012-13$ & 3767.27 & 911.33 & 2149.52 & 1184.59 & 1223.99 & 2199.87 & 4932.20 & 3914.60 & 20283.37 \\
\hline 2013-14 & 5212.04 & 149.79 & 2261.38 & 2158.69 & 1265.20 & 5735.17 & 4358.77 & 6089.60 & 27230.64 \\
\hline 2014-15 & 1387.48 & 446.06 & 3740.43 & 1347.27 & 1726.27 & 5984.34 & 3450.09 & 7589.60 & 25671.57 \\
\hline \multicolumn{10}{|c|}{ Two-way ANOVA } \\
\hline \multicolumn{9}{|l|}{ Variation } & F Crit \\
\hline Rows & \multicolumn{2}{|c|}{16963883.0766} & \multicolumn{2}{|l|}{4} & \multicolumn{2}{|c|}{4240970.76915} & 2.83317 & 0.043206 & 2.7141 \\
\hline Columns & \multicolumn{2}{|c|}{104875053.38} & \multirow{2}{*}{\multicolumn{2}{|c|}{$\begin{array}{l}7 \\
28\end{array}$}} & \multirow{2}{*}{\multicolumn{2}{|c|}{$\begin{array}{l}14982150.4829 \\
1496896.6512\end{array}$}} & 10.009 & 3.2649357 & 2.3593 \\
\hline Error & \multirow{2}{*}{\multicolumn{2}{|c|}{$\begin{array}{l}41913100.234 \\
163752042.6917\end{array}$}} & & & & & & & \\
\hline Total & & & \multicolumn{2}{|l|}{39} & \multicolumn{2}{|c|}{1496896.6512} & & & \\
\hline
\end{tabular}

Source: Annual Reports of Canara Bank

Borrowings carry a relatively low rate of interest while deposits carry a high rate of interest. The overall cost of funds raised by banks depends upon the maturity pattern also. The higher the concentration of low rate liabilities in the time buckets of smaller duration the lower the level of financial risk and vice versa. Table 6 indicates that there is a heavy concentration of liabilities in the time bucket of over 5 years. Hence, it is inferred that the overall cost of debt is not influenced much by the borrowings.

\section{Analysis of Maturity Pattern of Interest-bearing Liabilities}

The analysis of maturity pattern of interest-bearing liabilities throws light on liquidity aspect and the level of financial productivity. The higher the volume of interest-bearing liabilities falling under the time bucket of longer maturity the higher the level of financial risk and vice versa. The concentration of interest-bearing liabilities in the time buckets of smaller and smaller durations the bank needs more funds for meeting the liquidity requirements and its profitability would be adversely affected. Table 7 provides the details of the maturity pattern of interest-bearing liabilities.

Table 7

Analysis of Maturity Pattern of Interest-bearing Liabilities

(Rs. in Crore)

\begin{tabular}{|c|c|c|c|c|c|c|c|c|c|}
\hline Year & $\begin{array}{l}1 \text { Day to } \\
14 \text { Days }\end{array}$ & $\begin{array}{l}15 \text { Days to } \\
28 \text { Days }\end{array}$ & $\begin{array}{l}29 \text { Days to } \\
3 \text { Months }\end{array}$ & $\begin{array}{l}3 \text { Months } \\
\text { to } 6 \\
\text { Months }\end{array}$ & $\begin{array}{l}6 \text { Months to } \\
1 \text { Year }\end{array}$ & $\begin{array}{l}1 \text { Year to } 3 \\
\text { Years }\end{array}$ & $\begin{array}{l}3 \text { Years to } \\
5 \text { Years }\end{array}$ & $\begin{array}{l}\text { Over } 5 \\
\text { Years }\end{array}$ & Total \\
\hline $2010-11$ & 24602.54 & 7042.55 & 35322.05 & 21916.30 & 69332.94 & 51310.35 & 42006.15 & 56701.43 & 308234.30 \\
\hline 2011-12 & 15591.39 & 4764.93 & 35669.03 & 30777.51 & 93132.37 & 49895.96 & 42956.51 & 69791.43 & 342579.12 \\
\hline 2012-13 & 27233.34 & 6951.49 & 35344.05 & 22466.02 & 81047.86 & 59929.34 & 53559.56 & 79607.72 & 376139.36 \\
\hline 2013-14 & 50627.04 & 14403.79 & 43821.38 & 37742.69 & 130057.20 & 134792.17 & 15590.77 & 20921.60 & 447954.64 \\
\hline 2014-15 & 33852.33 & 16667.73 & 49923.25 & 39879.21 & 134163.97 & 173359.97 & 24893.90 & 26781.28 & 499511.67 \\
\hline \multicolumn{10}{|c|}{ Two-way ANOVA } \\
\hline $\begin{array}{l}\text { Source of } \\
\text { Variation }\end{array}$ & \multicolumn{2}{|l|}{ SS } & \multicolumn{2}{|l|}{ Df } & MS & \multicolumn{2}{|c|}{$\mathrm{F}$} & P-Value & F Crit \\
\hline Rows & \multicolumn{2}{|c|}{3102000822.30} & \multicolumn{2}{|l|}{4} & \multicolumn{2}{|l|}{775500205.58} & 1.20175 & 0.33202 & 2.71407 \\
\hline Columns & \multirow{2}{*}{\multicolumn{2}{|c|}{$\begin{array}{l}36208806379.21 \\
18068614940.10\end{array}$}} & 7 & & \multirow{2}{*}{\multicolumn{3}{|c|}{$\begin{array}{l}5172686625.60 \\
64530767643\end{array}$}} & 0.00002 & 2.35925 \\
\hline Error & & & 28 & & & & & & \\
\hline Total & \multicolumn{2}{|c|}{57379422141.61} & 39 & & & & & & \\
\hline
\end{tabular}

Source: Annual Reports of Canara Bank 
Table 7 revealed that interest-bearing liabilities are highly concentrated in the time bucket of 1 to 3 years. This signifies that overall cost of debt of the bank is influenced much by the interest-bearing liabilities of the longer maturity period.

\section{Analysis of Maturity Gap:}

Bank's capacity to earn an optimum return on total funds deployed depends upon risk-return trade-off principle. The magnitude of interest income to be earned by the bank depends upon the interest rate and duration of the asset. The higher the rate of return and the longer the duration of the asset, the more will be the return and vice versa. Similarly, the average cost of funds raised by the bank depends upon the interest rate and duration of the liabilities. If the funds raised are bearing a high rate of interest and the loan duration is more, the cost of debt will be high and vice versa.

Besides their influence on bank's profitability, the maturity pattern and duration of assets and liabilities would affect the bank's liquidity also. The mismatch between the rates of interest applicable to funds raised and funds deployed and the duration of assets and liabilities would affect the liquidity position of the bank. In nutshell, it may be said that the bank's ultimate power to create financial wealth for its shareholders depends on its trade-off between liquidity and profitability. Against this background, an attempt has been made in this section to examine the characteristics of Asset-Liability management by the bank under study with the help of GAP analysis.

Table 8

Analysis of Maturity Gap (1-14 Days)

\begin{tabular}{llll} 
& & & Mismatch \\
\hline Year & Total Inflows & Total Outflows & -2071.18 \\
$2010-11$ & 22531.36 & 24602.54 & 12059.82 \\
$2011-12$ & 27651.19 & 15591.37 & -6222.76 \\
$2012-13$ & 21010.58 & 27233.34 & -15541.42 \\
$2013-14$ & 35085.62 & 50627.04 & 6134.71 \\
$2014-15$ & 39987.04 & 33852.33 & Total Outflows \\
t-Test & & 30381.324 \\
& Total Inflows & 170995946.5 \\
Mean & 29253.158 & 5 \\
Variance & 66230699.42 & \\
Observations & 5 & \\
Pooled Variance & 118613323 & \\
Hypothesized Mean Difference & 0 & \\
Df & 8 & \\
t Stat & -0.163785811 & \\
P(T<=t) one-tail & 0.436981003 & \\
$t$ Critical one-tail & 1.859548033 & \\
P(T<=t) two-tail & 0.873962005 & \\
$t$ Critical two-tail & 2.306004133 & \\
Sourt Ant & & \\
\end{tabular}

Source: Annual Reports of Canara Bank

Table 8 reveals that except in 2010-11, 2012-13 and 2013-14 the maturity gap (1 to 14 days) has been negative in view of RSAs being less than RSLs. Hence, the net interest income will be negatively affected when interest rates rise or fall by equal amounts. It also shows that negative gap has witnessed a trend of fluctuations over the period.

Table 9

Analysis of Maturity Gap (15 to 28 Days)

\begin{tabular}{|c|c|c|c|c|}
\hline & & & & (Rs. in Crore) \\
\hline Year & Total Inflows & Total Outflows & Mismatch & \\
\hline 2010-11 & 7327.64 & 7042.55 & 285.09 & \\
\hline 2011-12 & 8995.45 & 4764.93 & 4230.52 & \\
\hline $2012-13$ & 11094.24 & 6951.47 & 4142.77 & \\
\hline 2013-14 & 16861.41 & 14403.79 & 2457.62 & \\
\hline 2014-15 & 14928.87 & 16657.73 & -1734.86 & \\
\hline t-Test & & & & \\
\hline
\end{tabular}




\begin{tabular}{lll}
\hline & Total Inflows & Total Outflows \\
Mean & 11841.52 & 9964.094 \\
Variance & 15941170 & 27289573 \\
Observations & 5 & 5 \\
Pooled Variance & 21615372 & \\
Hypothesized Mean Difference & 0 & \\
Df & 8 & \\
t Stat & 0.638487 & \\
P(T<=t) one-tail & 0.2705 & \\
t Critical one-tail & 1.859548 & \\
P(T<=t) two-tail & 0.541 & \\
t Critical two-tail & 2.306004 & \\
Source: Annual Rep
\end{tabular}

Source: Annual Reports of Canara Bank

Table 9 reveal that maturity gap has been positive except during 2014-15. Hence, the bank's liquidity risk is lower as RSAs during this period have been higher than RSLs in this time bucket.

Table 10

Analysis of Maturity Gap (29 Days to 3 Months)

\begin{tabular}{llll} 
& & & \\
\hline Year & Total Inflows & Total Outflows & Mismatch \\
\hline $2010-11$ & 36374.22 & 35322.05 & 1052.17 \\
$2011-12$ & 33482.03 & 35669.03 & 2187.00 \\
$2012-13$ & 31655.07 & 45344.05 & -13688.98 \\
$2013-14$ & 23107.82 & 43821.38 & -20713.56 \\
$2014-15$ & 35002.90 & 49923.25 & -14920.35 \\
t-Test & & & Total Outflows \\
& & 31924.41 & 42015.95 \\
Mean & & 27377223 & 40488228 \\
Variance & 5 & 5 \\
Observations & & 33932726 & \\
Pooled Variance & & 0 & \\
Hypothesized Mean Difference & 8 & \\
Df & -2.73917 & \\
t Stat & 0.012741 & \\
P(T<t) one-tail & 1.859548 & \\
t Critical one-tail & 0.025482 & \\
P(T<=t) two-tail & 2.306004 & \\
t Critical two-tail & & & \\
\hline Source: Annual Reports & \\
\hline
\end{tabular}

Source: Annual Reports of Canara Bank

Table 10 indicates a negative maturity gap during the study period except in 2010-11 and 2011-12. It indicates that the bank has faced the problem of liquidity risk during the period. The RSAs are higher than RSLs during the study period except in 2006. It implies that the bank has not faced much of interest rate risk because NII would not come down whenever the interest rates increase and vice versa. 
Table 11

Analysis of Maturity Gap (3 Months to 6 Months)

\begin{tabular}{llll} 
& & & Mismatch \\
\hline Year & Total Inflows & Total Outflows & -985.32 \\
$2010-11$ & 20930.98 & 21916.30 & -8790.09 \\
$2011-12$ & 21987.42 & 30777.51 & 21.96 \\
$2012-13$ & 22487.98 & 22466.02 & -14939.69 \\
$2013-14$ & 22803.02 & 37742.69 & -15664.97 \\
$2014-15$ & 24232.24 & 39879.21 & \\
t-Test & & Total Outflows \\
& & Total Inflows & 30556.35 \\
Mean & 22488.33 & 69678004 \\
Variance & 1454125 & 5 \\
Observations & 5 & \\
Pooled Variance & 35566065 & \\
Hypothesized Mean Difference & 0 & \\
Df & 8 & \\
t Stat & -2.13904 & \\
P(T<=t) one-tail & 0.032437 & \\
t Critical one-tail & 1.859548 & \\
P(T<=t) two-tail & 0.064873 & \\
t Critical two-tail & 2.306004 & \\
Sourt Antal & &
\end{tabular}

Source: Annual Reports of Canara Bank

Table 11 provides the details of maturity gap during the 3 months to 6 months' time bucket. It is clear from the details in the table that the maturity mismatch has been negative throughout the study period except in 2012-13. The magnitude of mismatch has increased at an increasing ratio during the study period. It implies that the bank has faced the high level of interest risk when the interest rates increase. It would affect the liquidity and interest rate risk of the bank.

Table 12

Analysis of Maturity Gap (6 Months to 1 Year)

\begin{tabular}{llll} 
& & & \multicolumn{1}{c}{ (Rs. in Crore) } \\
\hline Year & Total Inflows & Total Outflows & Mismatch \\
\hline $2010-11$ & 33235.88 & 69332.94 & -36097.06 \\
$2011-12$ & 33773.27 & 93132.37 & -59359.10 \\
$2012-13$ & 41342.38 & 81047.86 & -39705.48 \\
$2013-14$ & 42362.65 & 130057.20 & -87694.55 \\
$2014-15$ & 52210.03 & 134163.97 & -81953.94 \\
t-Test & & \\
& & Total Inflows & Total Outflows \\
Mean & 40584.84 & 101546.9 \\
Variance & 59821054 & 851366159.098 \\
Observations & 5 & 5 \\
Pooled Variance & 455593606.64 & \\
Hypothesized Mean Difference & 0 & \\
Df & 8 & \\
t Stat & -4.51586 & \\
P(T<=t) one-tail & 0.00098 & \\
t Critical one-tail & 1.859548 & \\
P(T<=t) two-tail & 0.001961 & \\
t Critical two-tail & 2.306004 & \\
SOtrit Ant & &
\end{tabular}

Source: Annual Reports of Canara Bank

The maturity gap for the time bucket of 6 months to 1 year detailed in table 4.24 reflects the negative maturity gap as the expected cash outflows is more than the expected cash inflows during this maturity bucket. It implies an adverse impact on liquidity risk and interest rate risk with a hike in interest rates. Further, it also shows that the mismatch has 
increased in its magnitude over the period indicating thereby that the bank has not been able bridge the gap between the RSAs and the RSLs through proper planning and control.

Table 13

Analysis of Maturity Gap (1 Year to 3 Years)

\begin{tabular}{llll}
\multicolumn{1}{c}{} & & Mismatch & Rs. in Crore) \\
\hline Year & Total Inflows & Total Outflows & -976.59 \\
$2010-11$ & 50333.76 & 51310.35 & 11222.28 \\
$2011-12$ & 61118.24 & 49895.96 & 13159.00 \\
$2012-13$ & 73088.34 & 59929.34 & -46093.08 \\
$2013-14$ & 88697.09 & 134790.17 & -73886.85 \\
$2014-15$ & 99473.12 & 173359.97 & Total Outflows \\
t-Test & & 93857.16 \\
& & Total Inflows & 3222530805.53 \\
Mean & 74542.11 & 5 \\
Variance & 397569165.283 & \\
Observations & 5 & \\
Pooled Variance & 1810049985.40 & \\
Hypothesized Mean Difference & 0 & \\
Df & 8 & \\
t Stat & -0.71783 & \\
P(T<=t) one-tail & 0.246645 & \\
t Critical one-tail & 1.859548 & \\
P(T<=t) two-tail & 0.493289 & \\
t Critical two-tail & 2.306004 & \\
Sour & &
\end{tabular}

Source: Annual Reports of Canara Bank

The analysis of maturity gap of 1-3 years' time bucket of the bank indicates that the maturity gap has been negative during the study period except during 2011-12 and 2012-13. The mismatch between RSAs and RSLs is quite wide. It means that the bank has not been facing the problem of liquidity and interest rate in respect of assets and liabilities during this time bucket.

Table 14

Analysis of Maturity Gap (3 Years to 5 Years)

\begin{tabular}{llll}
\multicolumn{1}{c}{} & & Ms. in Crore) \\
\hline Year & Total Inflows & Total Outflows & -11883.92 \\
\hline $2010-11$ & 30122.23 & 42006.15 & -5327.65 \\
$2011-12$ & 37628.86 & 42956.51 & -11571.21 \\
$2012-13$ & 41988.35 & 53559.56 & 42476.52 \\
$2013-14$ & 58067.29 & 15590.77 & 43575.55 \\
$2014-15$ & 68469.45 & 24893.90 & \\
t-Test & & Total Outflows \\
& & Total Inflows & 35801.38 \\
Mean & 47255.24 & 233122472.37 \\
Variance & 245222621.24 & 5 \\
Observations & 5 & \\
Pooled Variance & 239172546.80 & \\
Hypothesized Mean Difference & 0 & \\
Df & 8 & \\
t Stat & 1.171025 & \\
P(T<=t) one-tail & 0.137642 & \\
t Critical one-tail & 1.859548 & \\
P(T<=t) two-tail & 0.275285 & \\
t Critical two-tail & 2.306004 & \\
Solt & &
\end{tabular}

Source: Annual Reports of Canara Bank 
The analysis of maturity gap of 3 to 5 years' time bucket of the bank shows that maturity gap between the Rate Sensitive Assets (RSAs) and the Rate Sensitive Liabilities (RSLs) has been negative except during 2013-14 and 2014-15. It indicates that the gap has increased over the study period indicating the unfavourable effect of an unexpected change in interest rates on the NII.

Table 15

Analysis of Maturity Gap (Over 5 Years)

\begin{tabular}{llll} 
& & & \\
\hline Year & Total Inflows & Total Outflows & Mismatch \\
\hline $2010-11$ & 95311.03 & 56701.43 & 38609.60 \\
$2011-12$ & 109910.78 & 69791.43 & 40119.35 \\
$2012-13$ & 121179.51 & 79607.72 & 41571.79 \\
$2013-14$ & 140952.41 & 20921.16 & 120031.25 \\
$2014-15$ & 141084.04 & 26781.28 & 114302.76 \\
t-Test & & Total Outflows \\
& & 50760.6 \\
Mean & 121687.6 & 673755562.762 \\
Variance & 395507469.6811 & 5 \\
Observations & 5 & \\
Pooled Variance & 534631516.221 & \\
Hypothesized Mean Difference & 0 & \\
Df & 8 & \\
t Stat & 4.850137 & \\
P(T<=t) one-tail & 0.000636 & \\
t Critical one-tail & 1.859548 & \\
P(T<=t) two-tail & 0.001272 & \\
t Critical two-tail & 2.306004 & \\
Source: Annual Reports & & \\
\hline
\end{tabular}

Source: Annual Reports of Canara Bank

Table 15 reveals that the maturity gap over 5 years has been positive for all the years total inflows are more than total outflows.

\section{Conclusion}

The analysis of the maturity pattern of RSAs and RSLs classified under eight different maturity time buckets reveals that the maturity gap has been negative in respect of assets and liabilities maturing within a period of 3 years and was positive in respect of assets and liabilities maturing beyond 3 years. Hence, it is inferred that negative effect of unexpected changes on the interest rates on the bank's NII in respect of assets and liabilities maturing within short period time buckets is neutralized by the positive effect of assets and liabilities maturing during the long period. Hence, the impact of gap management on bank's NII has been positive during the study period.

\section{Findings:}

a) There are no significant variations in the maturity pattern of loans and advances, investments, and interestearning assets among different time buckets.

b) There are no significant variations in maturity pattern of liabilities until different time buckets.

c) There are significant variations in the maturity gaps of total inflows and total outflows under different time buckets except for time bucket over 5 years.

\section{Suggestions:}

a) The bank has ensured perfect maturity between assets and liabilities under different time buckets so that its liquidity power is not impaired. 
b) Periodical review of mismatches occurring during the subsequent to the period of deposits mobilised or credit sanctions is to be undertaken by ALM committee.

c) ALM literacy campaign may arrange by the bank as part of human resource management and human resource development so as to prevent mismatches at least in future.

\section{Acknowledgements}

The author would like to thank the editor for their valuable time and advice. 


\section{References}

Adetunji, A. T., Adetunji, A. V., Adeleke, E. O., \& Madubuike, S. C. (2017). Deregulation: The Effect of Market-led Approach to Nigerian Universities Management. International Journal of Social Sciences and Humanities (IJSSH), 1(1), 1-8.

Arora, P., Garg, A., \& Ranjan, B. (2012). The ALM practices in commercial banks in India.

Chakraborty, S., \& Mohapatra, S. (2009). An Empirical Study of Asset Liability Management Approach by Indian Banks.

Dewi, I. G. A. A. O., \& Dewi, I. G. A. A. P. (2017). Corporate Social Responsibility, Green Banking, and Going Concern on Banking Company in Indonesia Stock Exchange. International Journal of Social Sciences and Humanities (IJSSH), 1(3), 118-134.

Gavin, J. J. (2001). Asset-Liability Management.

Jain, P. K., \& Gupta, V. (2004). Asset-Liability Management among Commercial Banks in India-A Canonical Correlation Analysis. Vision, 8(1), 25-40.

Jayanal Uddin Ahemed. (2007). Asset Liability Absurdity of Public Sector Commercial Banks in India - An Exploration. Indian Economic Panorama, 17(2) July 2007.

Kapil Sharma. (2002). Asset-Liability Management Approach by Indian Banks for Risk Management .Business and Management Education, AIMS.

Lileikiené, A. (2008). Analysis of chosen strategies of asset and liability management in commercial banks. Engineering Economics, 57(2).

Suardana, I. B. R., Astawa, I. N. D., \& Martini, L. K. B. (2018). Influential Factors towards Return On Assets and Profit Change. International Journal of Social Sciences and Humanities (IJSSH), 2(1), 105-116. 